\title{
ISOLATION AND CHARACTERIZATION OF PROTEINASE AND COLLAGENASE FROM CL. HISTOLYTICUM ${ }^{1,2}$
}

\author{
By INES MANDL, JOHN D. MAcLENNAN, AND EDWARD L. HOWES with the \\ TECHNICAL ASSISTANCE OF ROBERT H. DeBELLIS ANd ARTHUR SOHLER \\ (From the Departments of Surgery and Microbiology, College of Physicians and Surgeons, \\ Columbia University, New York, N. Y.)
}

(Submitted for publication February 20, 1953 ; accepted August 18, 1953)

\section{INTRODUCTION}

Reports on the nature of proteolytic enzymes obtained from $\mathrm{Cl}$. histolyticum have been contradictory. Maschmann (1) described two extracellular and one intracellular enzymes besides peptidases. $\mathrm{His}$ extracellular proteinases are inhibited by cysteine, $\mathrm{Fe}^{++}, \mathrm{Cu}, \mathrm{Hg}$ and cysteine plus $\mathrm{Fe}^{++}$. Weil and Kocholaty (2), on the other hand, found a proteinase activated by heavy metals and $\mathrm{SH}^{-}$ compounds. Van Heyningen (3) tried to reconcile both findings by postulating two proteinases, one activated by cysteine, the other inhibited, so that the addition of cysteine to a system containing both enzymes would be without obvious effect. More recently, Kocholaty and Krejci (4) found that by salt precipitation they obtained one single proteinase only, activated by $\mathrm{Fe}^{++}$and cysteine. Collagenase activity of $\mathrm{Cl}$. histolyticum has been reported by Jennison (5), Evans (6), Oakley and Warrack (7), and Neumann and Tytell (8). Tytell and Hewson (9) prepared both a collagen-digesting enzyme inhibited by $\mathrm{Fe}^{++}$and cysteine and a proteinase resembling that of Kocholaty and Krejci (4) and Van Heyningen (3). A similar proteinase has now been isolated by Lepow, Katz, Pensky, and Pillemer (10) except that their purified enzyme is optimally activated by cysteine alone, $\mathrm{Fe}^{++}$being without effect.

Our own studies of $\mathrm{Cl}$. histolyticum enzymes have led us to the conclusion that all strains elaborate a collagenase and at least one other proteolytic enzyme. The amounts vary with the strains and with the medium used. Elsewhere (11) the screening of organisms was described for the selec-

1 This work supported in part by a grant from the Medical Research and Development Board, Office of the Surgeon General, Department of the Army, Contract No. DA 49-007-md-14.

2 Presented in part at the American Chemical Society Meeting, Atlantic City, Fall 1952. tion of strains capable of producing large amounts of potent enzymes that digested native and denatured collagen. By differential precipitation techniques we have now been able to isolate some of these enzymes from media growing certain of these strains.

\section{Precipitation of proteinase}

Optimum growth conditions for proteinase production are described in a previous paper (11). After 17 hours incubation the fluid medium containing the enzyme is freed of bacteria by passage through a large Seitz filter. It is then subjected to fractional precipitation under controlled conditions of temperature, $\mathrm{pH}$ and ionic strength. Methanol precipitation gives a more active and purer proteinase than precipitation with acetone, ethanol, propanol and butanol. Relatively high concentrations of 66 to 72 per cent methanol, $\mathrm{pH}$ of 6.1 to 6.2 and high ionic strength of 0.27 were found most satisfactory (see Tables I and II). At high ionic strength only traces of collagenase are co-precipitated.

The cooled filtrate adjusted to $\mathrm{pH} 6.1$ is precipitated at $-5^{\circ} \mathrm{C}$. with 2 to $2 \frac{1}{2}$ vol. methanol precooled to -15 to $-20^{\circ} \mathrm{C}$. The precipitate is allowed to settle overnight at a temperature of $-15^{\circ} \mathrm{C}$., then spun off in a refrigerated centrifuge. It is resuspended in a small amount of water, dialyzed, clarified by filtration or centrifugation and lyophilized to a white powder.

The small amount of collagenase co-precipitated under these conditions comes down with the first $1 \frac{1}{2}$ vol. methanol. When this fraction was centrifuged off and a further volume of methanol added to the supernatant, the second precipitate so obtained was a proteinase of high activity and completely free of collagenase (Fraction II). A1though these enzyme preparations appear electrophoretically homogenous (Figure 1), they contain relatively large amounts of a saccharide im- 
TABLE I*

Precipitation of $\mathrm{Cl}$. hystolyticum proteinase under varying conditions

\begin{tabular}{|c|c|c|c|c|}
\hline $\begin{array}{l}\mathrm{Vol}_{\text {- }} \\
\mathrm{CH}_{3}{ }^{\mathrm{H}}\end{array}$ & $\mathrm{pH}$ & $\begin{array}{c}\text { Azocoll } \\
\text { test }\end{array}$ & & $\begin{array}{c}\text { Casein } \\
\text { test (15) }\end{array}$ \\
\hline $\begin{array}{l}\frac{1}{2} \\
\frac{3}{4}\end{array}$ & $\begin{array}{l}7.5 \\
7.5\end{array}$ & \multicolumn{3}{|c|}{$\begin{array}{l}\text { no ppt } \\
\text { no ppt }\end{array}$} \\
\hline $1^{4}$ & 7.5 & 52 & & 85 \\
\hline $1 \frac{1}{2}$ & 7.5 & 70 & & 90 \\
\hline $2 \dagger$ & 7.5 & 170 & & 197 \\
\hline & $--\cdots$ & $-\cdots$ & --- & \\
\hline $1 \frac{1}{2}$ & 5.5 & 19 & & 84 \\
\hline $1 \frac{1}{2} \dagger$ & 6.0 & 60 & & 180 \\
\hline $1 \frac{1}{2}$ & 6.6 & 43 & & 175 \\
\hline $1 \frac{1}{2}$ & 7.0 & 38 & & 139 \\
\hline $1 \frac{1}{2}$ & 7.5 & 35 & & 90 \\
\hline $1 \frac{1}{2}$ & 8.4 & 25 & & 90 \\
\hline & $-\cdots--$ & -- & --- & \\
\hline $2 \dagger$ & 6.1 & 520 & & 268 \\
\hline 2 & 6.3 & 199 & & 158 \\
\hline 2 & 6.55 & 186 & & 155 \\
\hline 2 & 6.65 & 143 & & 142 \\
\hline 2 & 6.85 & 157 & & 152 \\
\hline
\end{tabular}

* Azocoll and Casein digestion values are given as comparative colorimetric readings per unit volume.

† Optimal conditions.

purity which was found to be Blood Group A substance, co-precipitated from the peptone in the medium. This anti-hemagglutination factor, which is present in relatively large amounts in most mammalian tissue digests, is not precipitated to the same extent by $\left(\mathrm{NH}_{4}\right)_{2} \mathrm{SO}_{4}$. The amount of contaminant was, therefore, substantially reduced by preliminary precipitation of both enzymes with $\left(\mathrm{NH}_{4}\right)_{2} \mathrm{SO}_{4}$. Forty per cent $\left(\mathrm{NH}_{4}\right)_{2} \mathrm{SO}_{4}$ precipitated collagenase containing 20 to 40 per cent proteinase activity ( 35 per cent by weight). This proteinase could be separated by methanol precipitation of the dialysed collagenase preparation at

TABLE II *

Effect of ionic strength and ions present on enzyme activity of precipitate ( $p \mathrm{H} \mathrm{6.1,2}$ vol. $\mathrm{CH}_{3} \mathrm{OH}$ added)

\begin{tabular}{lccccr}
\hline $\begin{array}{c}\text { Ions } \\
\text { present }\end{array}$ & $\begin{array}{c}\text { MgSO } \\
\text { added } \\
(m g .)\end{array}$ & $\begin{array}{c}\text { Ionic } \\
\text { strength }\end{array}$ & $\begin{array}{c}\text { Azocoll } \\
\text { test }\end{array}$ & $\begin{array}{c}\text { Casein } \\
\text { test } \\
(15)\end{array}$ & $\begin{array}{c}\text { B.A.A. } \\
\text { test } \\
(17)\end{array}$ \\
\hline $\mathrm{Fe}^{++}$ & 0 & 0.1 & 166 & 238 & 77 \\
$\mathrm{Fe}^{++}$ & 32 & 0.112 & 106 & 197 & 92 \\
$\mathrm{Fe}^{++}$ & 160 & 0.16 & 169 & 252 & 206 \\
$\mathrm{Fe}^{++}$ & 320 & 0.22 & 206 & 286 & 280 \\
$\mathrm{Fe}^{++}$ & -- & --- & -- & -- & \\
$\mathrm{Mn}^{++}$ & 0 & 0.1 & 709 & 208 & 210 \\
$\mathrm{Mg}^{++}$ & 0 & 0.1 & 690 & 185 & 240 \\
$\mathrm{Co}^{++}$ & 0 & 0.1 & 520 & 171 & 160 \\
& 0 & 0.1 & 510 & 149 & 240
\end{tabular}

* Azocoll, Casein and Benzoyl Arginine Amide digestion values are given as comparative colorimetric readings per unit volume.
$\mathrm{pH} 7.5$ in the presence of enough $\mathrm{MgSO}_{4}$ to raise the ionic strength to 0.27 . The resulting enzyme preparation was free of collagenase and very active. Experiments on the further purification of this proteinase both by chemical and physico-chemical means are in progress.

\section{Precipitation of collagenase}

Precipitation of the clear Seitz filtrate with solid $\left(\mathrm{NH}_{4}\right)_{2} \mathrm{SO}_{4}$ gives a very active enzyme preparation. Most of the activity is in a first fraction obtained by adding $400 \mathrm{Gm}$. solid $\left(\mathrm{NH}_{4}\right)_{2} \mathrm{SO}_{4}$ to each liter of filtrate, allowing it to stand at $4^{\circ} \mathrm{C}$. overnight, filtering, resuspending the precipitate in a little water, dialysing, filtering off any insoluble residue and freeze drying. Further purification may be obtained by calcium phosphate adsorption and elution with 10 per cent $\left(\mathrm{NH}_{4}\right)_{2} \mathrm{SO}_{4}$ or by a second $\left(\mathrm{NH}_{4}\right)_{2} \mathrm{SO}_{4}$ precipitation at more alkaline $\mathrm{pH}$, but in our hands these steps entail considerable losses. The dried enzyme is not free of proteinases.

An alternative method is $\mathrm{CH}_{3} \mathrm{OH}$ precipitation of the dialyzed Seitz filtrate essentially as described by Tytell and Hewson (9).

\section{Assay methods employed}

Azocoll: Various modifications of the method of Oakley, Warrack, and Van Heyningen (12) estimating the release of color from Azocoll (hide powder coupled to an azo dye) have been used to determine total proteolytic activity at consecutive steps of purification.

For quantitative determinations $50 \mathrm{mg}$. Azocoll are suspended in $9.9 \mathrm{ml}$. Phosphate Buffer $\mathrm{pH} 7.4$ containing 4 parts $\mathrm{M} / 15 \mathrm{Na}_{2} \mathrm{HPO}_{4}, 1$ part $\mathrm{M} / 15 \mathrm{KH}_{2} \mathrm{PO}_{4}$ and 5 parts 0.9 per cent $\mathrm{NaCl}$. One-tenth $\mathrm{ml}$. enzyme solution is added and the flasks shaken for exactly 15 minutes on a Fisher Gyrosolver shaking machine placed in an incu-

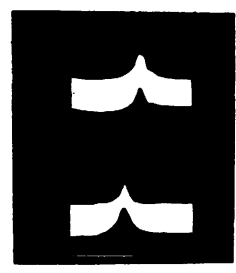

pH 4.15

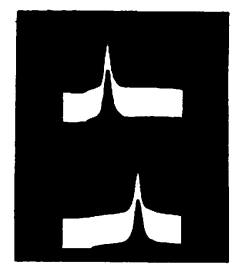

pH 5.5

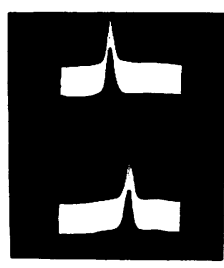

pH 7.25
Fig. 1. Electrophoretic Patterns of Cl. Histolyticum Proteinase 


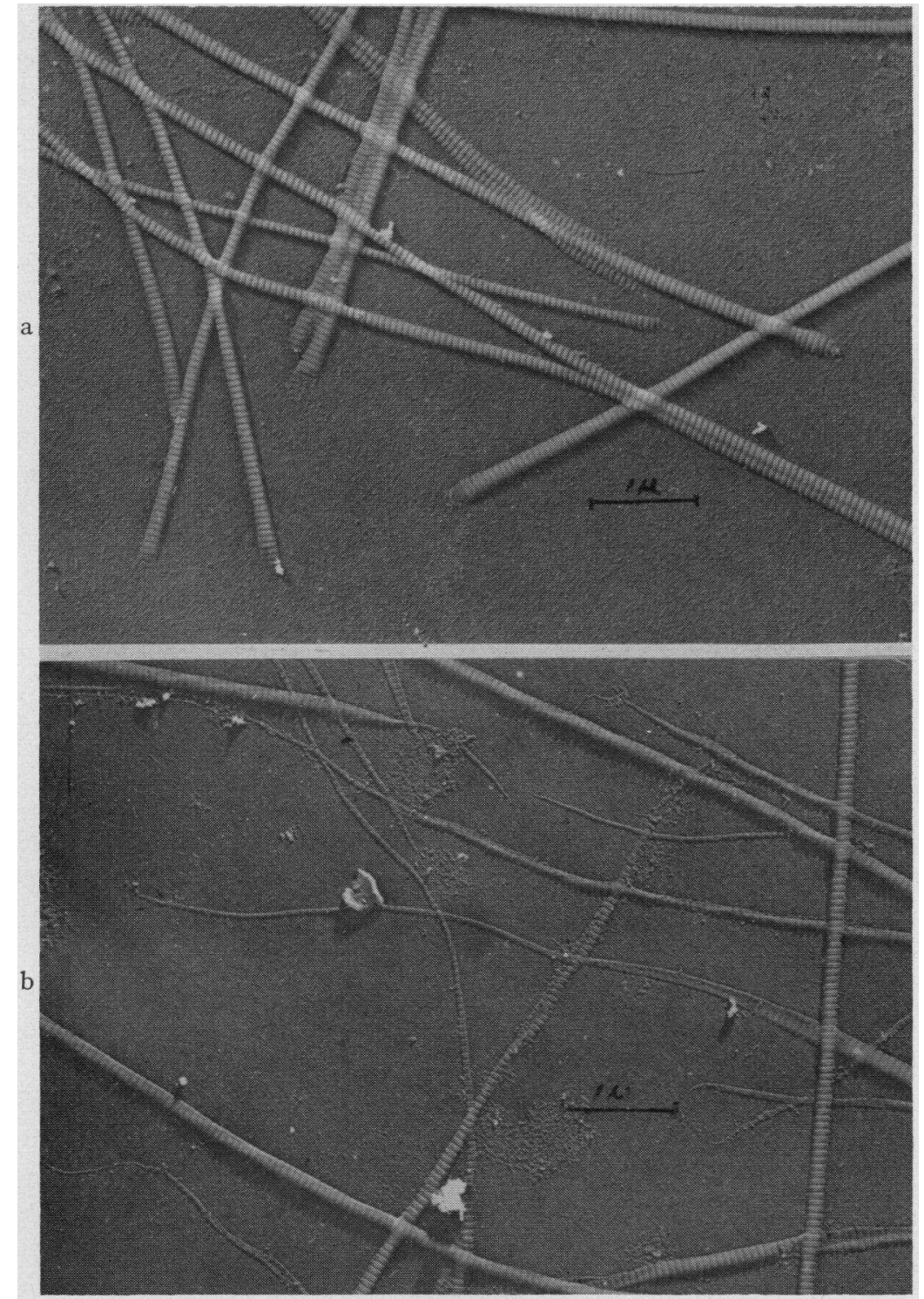

Fig. 2. Electron Micrographs Showing Effect of Collagenase on Collagen Fibrils. a. Untreated Fibrils. b. Collagenase Treated Fibrils (Preparation by Dr. Jerome Gross, Mass. Inst. of Technology)

bator at $37^{\circ} \mathrm{C}$. The Azocoll powder is then filtered off through a rapid filter paper directly into Klett tubes and the color released read in a colorimeter with a green filter No. 54. The Klett reading minus the blank is calculated for $1 \mathrm{mg}$. dry enzyme. This value indicates $Q$ units for this enzyme preparation. When the effect of added activators, inhibitors, metal salts, etc. is tested the amount cf buffer is decreased to give a total volume of $10 \mathrm{ml}$.

Native collagen: Unlike Azocoll or hide powder, which are attacked by collagenase and protein- ase (s), "undenatured" collagen is a specific substrate for collagenase. Collagenase activity was therefore determined by the action of the enzyme on Achilles tendon or collagen purified by extraction with $\mathrm{Na}_{2} \mathrm{HPO}_{4}$ and $\mathrm{KCl}$ to remove soluble proteins and mucopolysaccharides (13). The degree of hydrolysis was established by a modification of the ninhydrin color reaction (14) for free amino groups and $\mathrm{Kjeldahl}$ nitrogen tests or by serial dilution experiments. The extent of the 
breakdown of collagen by collagenase was estimated by occasional Van Slyke ninhydrin $\mathrm{CO}_{2}$ tests (15) to distinguish between peptides and free amino acids. These tests showed that at least some amino acids were released from collagen, although enzymatic digestion was not as complete as acid hydrolysis. Paper chromatograms of enzymatic and acid collagen hydrolysates confirmed these findings. Since all our collagenase preparations contain some proteinase this enzyme may be responsible for the liberation of free amino acids after breakdown to the peptide level by the collagenase. We are still engaged in the elucidation of this point.

Dr. Jerome Gross of Massachusetts General Hospital has studied the changes in the fine structure of undenatured collagen fibrils as influenced by collagenase and proteinase under the electron microscope. The proteinase either with or without cysteine activation did not attack collagen fibrils. On the other hand, the attack brought about by collagenase was very striking. The fibrils became distinctly tapered and lost their cross striations. Trypsin fragments the fibril transversely

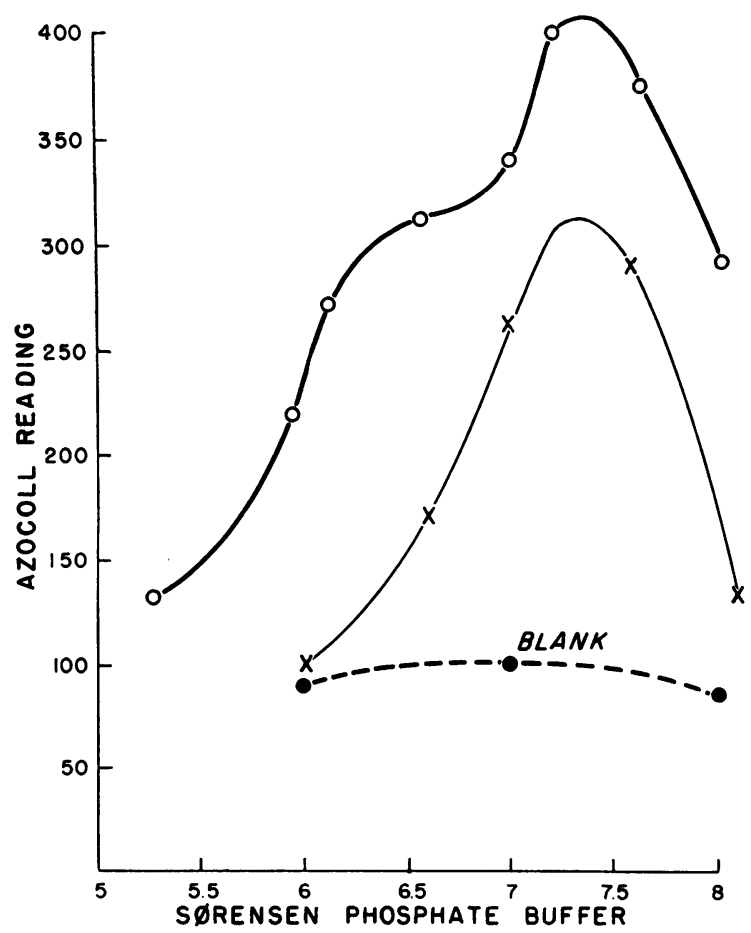

Fig. 3. Activity of Collagenase (o) and Proteinase $(\mathrm{x})$ in Sфrensen Phosphate Buffer

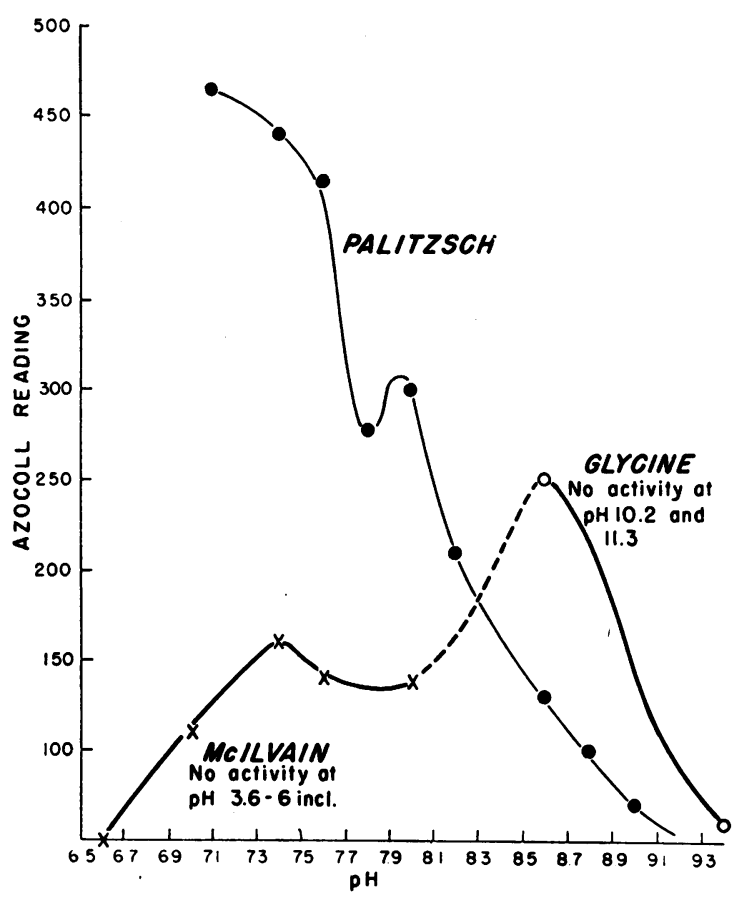

Fig. 4. Activity of Proteinase in Palitzsch, McIlvain, ANd Glycine Buffer

but collagenase reduced the entire diameter as if it were washed away (Figure 2).

Other tissue components: None of our preparations has had any activity against elastin or keratin.

Other substrates: Enzymatic activity of our preparations was also measured against various other substrates such as casein, egg albumen, bovine serum albumen, hemoglobin, etc. by adaptation of Kunitz' method (16) of determining the tyrosine and tryptophane content of the supernatant obtained on trichloroacetic acid precipitation of the digest. For casein hydrolysis the decrease in turbidity resulting on addition of aliquots to sulfosalicylic acid at given intervals according to Grob (17) was also followed. In addition, synthetic substrates such as benzoyl arginine amide, benzoyl arginine isopropyl ester and arginine methyl ester were employed. No activity was found against tyrosine ester or glycine ester. Activity against benzoyl arginine amide was measured by Conway microdiffusion of the $\mathrm{NH}_{3}$ released on splitting of the amide bond followed by nesslerization or titration by the method described for ficin (18). Hestrin's method (19) of reac- 


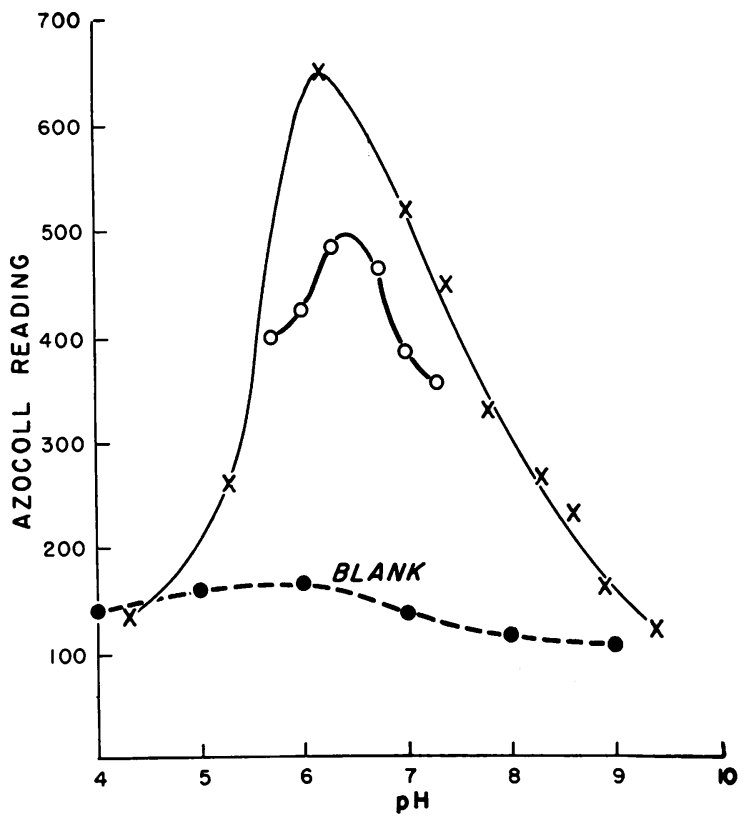

Fig. 5. Activity of Proteinase in Unbuffered Solution at Different $\mathrm{PH}$ Established by Adding $\mathrm{NAOH}$ OR $\mathrm{HC}_{L}$

tion with alkaline hydroxylamine was used to follow the decrease in unsplit ester present after enzymatic interaction.

\section{Chemical properties of proteinase and collagenase}

Both enzyme preparations are typical proteins, and give positive reactions with all the usual protein reagents. There is no evidence of free $\mathrm{SH}$ groups as judged by the nitroprusside reaction, although $\mathrm{S}$ is found on ashing. Their tyrosine and tryptophane content as determined by spectrophotometric analysis is low. These findings agree with those of Kocholaty and Krejci (4). The amino acid composition has been estimated by qualitative paper chromatography. It resembles that of collagen in both enzyme preparations. Quantitative analyses have been postponed until the purer enzymes are available.

In phosphate buffers both enzyme preparations showed maximum activity at $\mathrm{pH} 7.4$ (Figures 3,4 ) while with other buffers different maxima were obtained (Figure 4). Activities at a given $\mathrm{pH}$ also varied with the buffer employed. These differences are probably due to inhibition by some of the ions present-e.g., borate and citrate (Figure 4).
The collagenase-free proteinase was more thoroughly investigated first. Hence, the rest of the discussion about the factors that influence activity will be largely about proteinase.

In McIlvain phosphate-citrate buffer no proteinase activity was discerned below pH 6.6 (Figure $4)$; in Sørensen phosphate buffer, while the maximum activity occurred at the same $\mathrm{pH}$, the enzyme was active over a much wider range (Figure $3)$. An apparent second maximum in glycine buffer at $\mathrm{pH} 8.6$ was probably caused by the difference in buffer composition (Figure 4). In Palitzsch borate buffer activity decreased with rising $\mathrm{pH}$, with a possible slight maximum at $\mathrm{pH}$ 8 (Figure 4). When no buffer was used and $\mathrm{pH}$ adjusted with $\mathrm{HCl}$ and $\mathrm{NaOH}$ only, the maximum appeared at $\mathrm{pH} 6.4$ (Figure 5). It is of interest in this connection that in 1934, Walbum and Reymann (20) found two maxima, one between $\mathrm{pH}$ 6 to 7 and one between $\mathrm{pH} 8$ to 9 , for optimum gelatinase activity of crude $\mathrm{Cl}$. histolyticum filtrates. Since they too had to change the buffer systems from citrate ( $\mathrm{pH} 4$ to 5$)$ to phosphate $(\mathrm{pH} 6$ to 7$)$ to borate ( $\mathrm{pH} 8$ to 10$)$ the different effects of these anions may account for their results.

Stability at different $\mathrm{pH}$ values also differs with the buffer system employed. At low $\mathrm{pH}$, stability is greater in acetate than in McIlvain buffer (Figure 6). For at least one month stability of dilute solutions is fair over a $\mathrm{pH}$ range from about 5.6
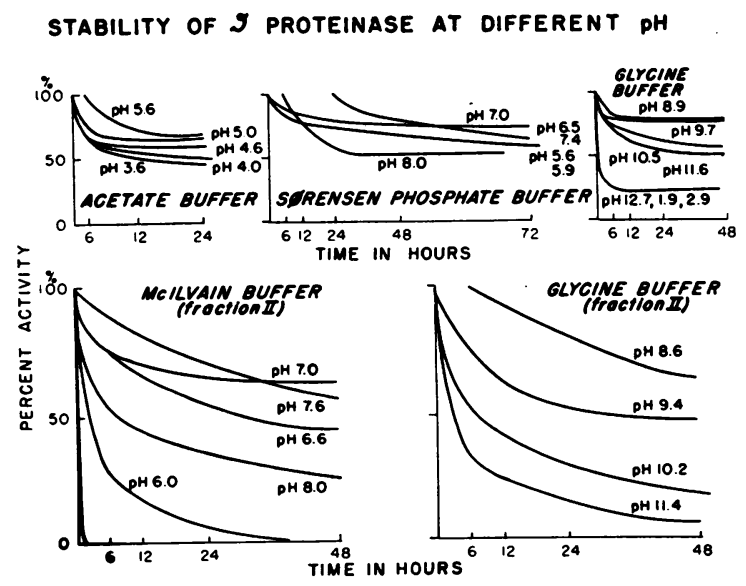

Fig. 6. Stability of Proteinase at Different pH's AND IN Different Buffers

Fraction II is a purer preparation. 
to high alkalinity, although stability is less for the more active highly purified preparations (Fraction II, Figure 6). In the dry state the lyophilized enzymes retain their activity indefinitely.

Table III shows the effect of various cations on proteinase activity. $\mathrm{Hg}^{++}$is seen to inhibit the enzyme completely, Ag considerably, most metal ions reduce proteinase activity to some extent, but $\mathrm{Ca}^{++}$increases it almost twofold; $\mathrm{Mg}, \mathrm{Co}$, and $\mathrm{Mn}$ activate slightly. Again, results differ somewhat with the system used, substrate and buffer (Table III).

The effects of oxidizing and reducing agents have been studied, but we were unable to confirm the cysteine activation or iodoacetamide inhibition claimed for $\mathrm{Cl}$. histolyticum proteinase $(2,4,7$, $9,10)$, except for the splitting of the synthetic substrates. At various concentrations and under various conditions of incubation, essentially unchanged activity toward Azocoll and casein was obtained in the presence or absence of cysteine or iodoacetamide. Very high concentrations of cysteine $(M / 10)$ showed definite inhibition of all enzyme preparations. Cysteine plus a heavy metal did not change the effect of the metal alone, except in the case of Co where the slight increase of activity with Co alone was no longer observed. The lack of cysteine activation led to the belief that we may be dealing with an enzyme distinct from the cysteine activated proteinase described by other workers $(2,4,7,9,10)$.

We have now further evidence for this third enzyme which we propose to call $\delta$ enzyme. This

TABLE III

Effect of various cations on $\delta$ proteinase activity

\begin{tabular}{|c|c|c|c|c|}
\hline \multirow[b]{2}{*}{ Metal } & \multirow{2}{*}{$\begin{array}{l}\text { Azocoll } \\
\text { reading in } \\
\text { McIlvain } \\
\text { buffer }\end{array}$} & \multirow{2}{*}{$\begin{array}{l}\text { Azocoll } \\
\text { reading in } \\
\text { Ca borate } \\
\text { buffer }\end{array}$} & \multicolumn{2}{|c|}{$\begin{array}{l}\text { Undigested } \\
\text { casein after }\end{array}$} \\
\hline & & & $1 \mathrm{hr}$. & $3 \mathrm{hrs}$. \\
\hline $\mathrm{Ca}$ & 540 & - & $\begin{array}{l}\% \\
18\end{array}$ & ${ }_{0}^{\%}$ \\
\hline $\mathrm{Mg}$ & 420 & 284 & 20 & 0 \\
\hline$Z_{\mathbf{n}}$ & 435 & 157 & 100 & 62 \\
\hline Mn & 415 & 240 & 25 & 0 \\
\hline $\mathrm{Fe}^{++}$ & 390 & 248 & 28 & 0 \\
\hline Co & 355 & 207 & 28 & $\mathbf{0}$ \\
\hline $\mathrm{Cu}$ & 340 & 23 (Blank) & 100 & 85 \\
\hline $\mathrm{Fe}^{+++}$ & 296 & 158 & 100 & 50 \\
\hline $\mathrm{Pb}$ & 250 & 131 & 100 & 40 \\
\hline $\mathrm{Ni}$ & 210 & 24 (Blank) & 100 & 100 \\
\hline $\mathrm{Ag}$ & 112 (Blank) & 41 (Blank) & 100 & 100 \\
\hline $\mathrm{Hg}$ & 100 (Blank) & $122 ?$ & 100 & 100 \\
\hline None (control) & 360 & 157 & 25 & 0 \\
\hline Blank & 150 & & 100 & 100 \\
\hline
\end{tabular}

TABLE IV

Titration of proteinase against Azocoll using different antisera*

\begin{tabular}{cccc}
\hline \hline Serum & Anti- $\beta$ & Anti- $\gamma$ & Anti- $\delta$ \\
\hline 2001 & 100 & 100 & 100 \\
2005 & 350 & 160 & 70 \\
2008 & 370 & 360 & 170 \\
2035 & 230 & 150 & 170 \\
8003 & 260 & 550 & 110 \\
8006 & 180 & 410 & 110
\end{tabular}

* The discrepancies between the anti- $\gamma$ and anti- $\delta$ readings will be obvious and indicate that these two proteinases are antigenically distinct. (Sera were kindly supplied by Dr. C. L. Oakley who calibrated them and who has largely confirmed our results.)

evidence, which will be given in greater detail elsewhere, can be summarized as follows: Tests conducted with a series of six specific antisera calibrated by Oakley and Warrack (7) for anti $\beta$ (collagenase) and anti $\gamma$ (cysteine activated proteinase) activity show that the new $\delta$ proteinase is immunologically distinct from both $\beta$ and $\gamma$ (see Table IV).

Heating of the proteinase preparation to $50^{\circ}$ for 30 minutes, lowering of the $\mathrm{pH}$ to 4.6 , or passage through a column of the ion exchange resin XE64 (Roehm and Haas) results in a loss of $2 / 3$ or more of the activity towards the synthetic substrates benzoyl arginine amide and arginine ester. This differential inactivation indicates the presence of at least two enzymes in the proteinase preparation. While collagenase is equally thermolabile and sensitive to lowering of $\mathrm{pH}$, losses in activity of proteinase preparations are too great to be accounted for by traces of collagenase present in some of our preparations and inactivation is the same when collagenase-free preparations are subjected to heat and low $\mathrm{pH}$.

We therefore found that at least three proteolytic enzymes are elaborated by $\mathrm{Cl}$. histolyticum: a collagenase identical with Oakley's $\beta$ enzyme, a cysteine activated proteinase, possibly Oakley's $\gamma$ enzyme, that attacks certain synthetic substrates and resists heat and low $\mathrm{pH}$ values and a new more labile proteinase, unaffected by cysteine and similar reducing agents.

\section{SUM MARY}

Conditions for the separation of proteolytic enzymes from $\mathrm{Cl}$. histolyticum have been established. A proteinase free of collagenase activity and a 
powerful collagenase, which, although it still contains' other proteinases, is considerably enriched and concentrated with regard to collagen digesting capacity have been isolated. The proteinase preparation has been investigated for the effect of $\mathrm{pH}$, cations and anions on its activity. Its stability has been determined. The main constituent of the proteinase preparation made by the method described is believed to be a new enzyme.

\section{ACKNOWLEDGMENTS}

We wish to thank Dr. C. L. Oakley of the University of Leeds, England, for calibrated antisera and a generous supply of Azocoll.

We are further indebted to Dr. Jerome Ġross, Massachusetts General Hospital for the electronmicrophotographs and permission to publish these before his own work is ready for press.

Dr. Harry Goldenberg of the Brooklyn Jewish Hospital very kindly put at our disposal the synthetic substrates benzoyl arginine isopropyl ester, arginine methyl ester, tyrosine ethyl ester and glycine ethyl ester, prepared by him.

The electrophoresis runs and photographs (Figure 1) were made by Dr. Daniel Moore of this institution.

\section{REFERENCES}

1. Maschmann, E., UUber Bakterienproteasen. IV. Mitteilung. Die Proteasen des B. Histolyticus. Biochem. Ztschr., 1937-38, 295, 391-399; see also IX. Mitteilung. Die Anaerobiase des Gasbranderregers. Biochem. Ztschr., 1938, 297, 284.

2. Weil, L., and Kocholaty, W., Studies on the proteinase of Clostridium histolyticum. Biochem. J., 1937, 31, 1255 ; see also Kocholaty, W., Weil, L., and Smith, L., Proteinase secretion and growth of Clostridium histolyticum. Biochem. J., 1938, 32, 1685.

3. Van Heyningen, W. E., The proteinases of Clostridium histolyticum. Biochem. J., 1940, 34, 1540.

4. Kocholaty, W., and Krejci, L. E., The activation mechanism and physico chemical properties of Clostridium histolyticum proteinase. Arch. Biochem., 1948, 18, 1.

5. Jennison, M. W., Bacterial collagenase. J. Bact., 1945, 50, 369; see also The collagenase activity of culture filtrates of Clostridium hystolyticum. J. Bact., 1947, 54, 55.

6. Evans, D. G., The production by certain species of Clostridium of enzymes disintegrating hide powder. J. Gen. Microbiol., 1947, 1, 378.
7. Oakley, C. L., and Warrack, G. H., The alpha, beta and gamma antigens of Clostridium histolyticum (Weinberg \& Séguin, 1916). J. Gen. Microbiol., 1950, 4, 365.

8. Neumann, R. E., and Tytell, A. A., Action of proteolytic enzymes on collagen. Proc. Soc. Exper. Biol. \& Med., 1950, 73, 409.

9. Tytell, A. A., and Hewson, K., Production, purification, and some properties of Clostridium histolyticum collagenase. Proc. Soc. Exper. Biol. \& Med., 1950, 74, 555.

10. Lepow, I. H., Katz, S., Pensky, J., and Pillemer, L., A cysteine-activated proteinase of Clostridium histolyticum. J. Immunol., 1952, 69, 435.

11. MacLennan, J. D., Mandl, I., Howes, E. L., Bacterial digestion of collagen. J. Clin. Invest., 1953, 32, 1317.

12. Oakley, C. L., Warrack, G. H., and Van Heyningen, W. E., The collagenase ( $\kappa$ toxin) of $\mathrm{Cl}$. welchii type A. J. Path. \& Bact., 1946, 58, 229.

13. Einbinder, J., and Schubert, M., Binding of mucopolysaccharides and dyes by collagen. J. Biol. Chem., 1951, 188, 335.

14. Harding, V. J., and MacLean, R. M., A colorimetric method for the estimation of amino-acid $\alpha$-nitrogen. J. Biol. Chem., 1915, 20, 217; see also Harding, V. J., and Warneford, F. H. S., The ninhydrin reaction with amino-acids and ammonium salts. $\mathrm{J}$. Biol. Chem., 1916, 25, 319.

15. Van Slyke, D. D., MacFadyen, D. A., and Hamilton, P., Determination of free amino acids by titration of the carbon dioxide formed in the reaction with ninhydrin. J. Biol. Chem., 1941, 141, 671.

16. Kunitz, M., Crystalline soybean trypsin inhibitor. II. General properties. J. Gen. Physiol., 1947, 30, 291 ; see also Northrop, J. H., Kunitz, M., Herriott, R. M., Crystalline Enzymes, ed. 2, rev. and enl., New York, Columbia Univ. Press, 1948, p. 308.

17. Grob, D., Proteolytic enzymes. I. The control of their activity. J. Gen. Physiol., 1946, 29, 219.

18. Mandl, I., and McLaren, A. D., The photochemistry of proteins. VII. A quantum yield for the inactivation of ficin by ultraviolet light. Arch. Biochem., 1949, $21,408$.

19. Hestrin, S., The reaction of acetylcholine and other carboxylic acid derivatives with hydroxylamine and its analytical application. J. Biol. Chem., 1949, $180,249$.

20. Walbum, L. E., and Reymann, G. C., Investigations into the nature of the gelatin-melting enzymes formed by the gas-gangrene bacteria; the importance of the degree of acidity of the medium for the action of the enzymes. J. Path. \& Bact., 1934, 39, 669. 